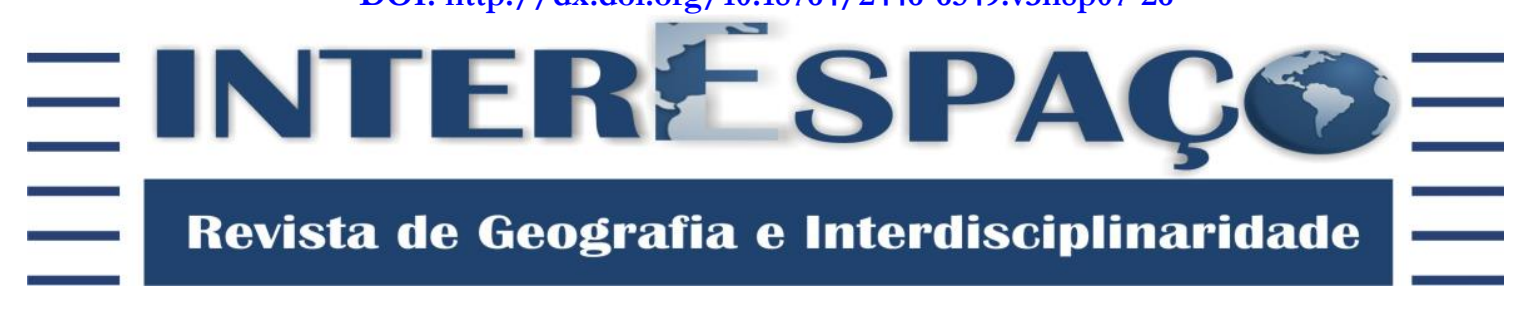

\title{
METHODOLOGY FOR RAPID ASSESSMENT OF ENVIRONMENTAL QUALITY OF WATER SPRINGS
}

\section{METODOLOGIA PARA AVALIAÇÃO RÁPIDA DA QUALIDADE AMBIENTAL DE NASCENTES}

\section{METODOLOGÍA PARA LA EVALUACIÓN RÁPIDA DE LA CALIDAD AMBIENTAL EN NACIENTES}

\section{Celso Henrique Leite Silva Junior}

Graduado em Engenharia Ambiental pela Universidade CEUMA - UniCEUMA e Mestrando pelo Instituto Nacional de Pesquisas Espaciais - INPE.

celsohlsj@gmail.com

\section{Denilson da Silva Bezerra}

Doutor em Ciências do Sistema Terrestre pelo Instituto Nacional de Pesquisas Espaciais - INPE.

Docente da Universidade CEUMA - UniCEUMA.

denilson_ca@yahoo.com.br

\section{Vera Lúcia Araújo Bezerra}

Mestra em Meio Ambiente e Desenvolvimento pela Universidade Federal do Ceará - UFC.

Docente da Universidade CEUMA - UniCEUMA.

vera.luarb@gmail.com

Gabrielle Vieira da Silva

Graduada em Engenharia Ambiental Universidade CEUMA - UniCEUMA. gabriellevsilva@hotmail.com

Ana Talita Galvão Freire

Graduada em Engenharia Ambiental Universidade CEUMA - UniCEUMA. talita.freire22@gmail.com

\section{Ana Emilia Figueiredo de Oliveira}

Doutora em Radiologia Odontológica pela Universidade Estadual de Campinas - UNICAMP.

Professora da Universidade Federal do Maranhão - UNA-SUS/UFMA. anaemilia@gmail.com

Recebido para avaliação em 13/01/2017; Aprovado para publicação em 20/02/2017.

\section{ABSTRACT}

This study has the objective of proposing a methodology for the rapid evaluation of the environmental quality of water springs, in the context of hydrographic basins. For this, 11 water springs of the Bacanga River were assessed. To calculate the Environmental Quality Index, it was adopted the Fuzzy operator, Weighted Mean AHP, which uses the methodology of the Analytical Hierarchy Process (AHP) to address the environmental factors involved in the index. Of the 11 analyzed springs, five were classified in class Very Good, three in class Good, two in class Reasonable and one water spring was classified as class Bad. No spring was framed in Class Very Bad. Therefore, we concluded that the use of fuzzy logic with AHP aid has proven to be effective in the environmental quality classification of springs, as it allows monitoring and subsides for the 
|Celso Henrique Leite Silva Junior | Denilson da Silva Bezerra | Vera Lúcia Araújo Bezerra | | Gabrielle Vieira da Silva | Ana Talita Galvão Freire | Ana Emilia Figueiredo de Oliveira |

management of this hydrological component. It was proposed that the water springs framed into classes Reasonable and $\mathrm{Bad}$ require mitigation measures for its environmental recovery. Urbanization has been identified as the main degradation agent of the springs studied here.

Keywords: Land Use and Land Cover Change; Fuzzy Logic; Analytical Hierarchy Process; Bacanga River.

\section{RESUMO}

O presente estudo tem como objetivo propor uma metodologia simplificada para a avaliação rápida da qualidade ambiental de nascentes, no contexto de bacias hidrográficas. Para isso, foram avaliadas 11 nascentes do Rio Bacanga. Para calcular o Índice de Qualidade Ambiental, adotou-se o operador Fuzzy Média Ponderada AHP, que utiliza a metodologia do Processo Analítico Hierárquico (AHP) para lidar com os fatores ambientais envolvidos no índice. Das 11 nascentes analisadas, cinco foram classificados na classe Muito Boa, três na classe Boa, duas na classe Razoável e uma nascente foi classificada na classe Ruim. Nenhuma nascente foi enquadrada na classe Muito Ruim. Portanto, concluímos que o uso da lógica Fuzzy com auxílio do AHP se mostrou eficaz na classificação da qualidade ambiental das nascentes, pois permite o monitoramento e subsídio para a gestão deste componente hidrológico. Sugere-se que para as nascentes enquadradas em classes Razoável e Ruim, sejam feitas intervenções para a recuperação ambiental destas. A urbanização desordenada foi identificada como o principal agente de degradação das nascentes estudadas.

Palavras-chave: Mudança de Uso e Cobertura do Solo; Lógica Fuzzy; Processo Analítico Hierárquico; Rio Bacanga.

\section{RESUMEN}

Este estudio tiene por objeto proponer una metodología simplificada para la evaluación rápida de la calidad ambiental de los muelles, en el contexto de las cuencas hidrográficas. Para ello, se evaluaron 11 cabeceras del Río Bacanga. Para calcular el Índice de Calidad Ambiental, aprobada el operador Fuzzy Promedio Ponderado AHP, que utiliza la metodología del Proceso Analítico Jerárquico (AHP) para hacer frente a los factores ambientales implicados en el índice. De los 11 manantiales analizados, cinco fueron clasificados como clase Muy bueno, tres como Bueno, dos en la clase Media y un resorte se clasificó en la clase Mala. Ninguna fuente se ha enmarcado en la clase Muy Malo. Por lo tanto, llegamos a la conclusión de que el uso de la lógica difusa con la ayuda de AHP fue eficaz en la clasificación de la calidad del medio ambiente de resortes, que permite el seguimiento y la provisión para la gestión de componente hidrológico. Se sugiere que, para los resortes enmarcados en las clases justos y pobres, las intervenciones se hacen para la recuperación ambiental de estos. La urbanización no planificada se ha identificado como el agente principal de la degradación de las aguas estudiadas.

Palabras clave: Cambio de Uso y Cobertura De La Tierra; La Lógica Difusa; Proceso Analítico Jerárquico; Río Bacanga.

\section{INTRODUCTION}

The quantity and the quality of water resources, in natural conditions, depend on climate, physical and biological characteristics of the ecosystems that compose them, such as factors like rain distribution, energy balance, geological formations and soil vegetal cover. Therefore, any change in the climate or landscape components will alter the quantity, quality and the water resistance time in the ecosystem, and also the water flow and 
|Celso Henrique Leite Silva Junior | Denilson da Silva Bezerra | Vera Lúcia Araújo Bezerra| | Gabrielle Vieira da Silva | Ana Talita Galvão Freire | Ana Emilia Figueiredo de Oliveira |

its characteristics, which may cause a situation of water insecurity (BARROS and AMIN, 2008).

Water is a common element to a wide range of issues, such as economic, environmental, social and political, including agriculture, energy, urban development, finances, trade and national security (PUP, 2015). As discussed in the UNESCO report, the demand for water comes, basically, from four activities: agriculture, accounting for the major share of $74 \%$ of its exploration, in BRICs (Brazil, Russia, India and China); energy production and electricity; industrial uses and human consumption (UN, 2012).

Regarding human consumption, the main demand source are urban centers, which require potable water for its inhabitants and water for sanitation and drainage. Based on projections of urban populations increase, from 3.4 billion in 2009 to 6.3 billion in 2050, it is expected that the urban areas of the world receive all population growth over the next four decades - as well as part of the rural population (UN, 2012). This will increment the demand for basic services, to the infrastructure overload and further increasing pressure on the availability and quality of natural resources.

Barros and Amin (2012) say that the quality of water resources is impacted by different forms of misuse and degradation, such as: excessive removal and its consequent waste; pollution and contamination by the release of raw sewage and, indirectly, by pesticides; deforestation; disorderly urbanization; and lack of management of aquatic ecosystems. It is noteworthy that despite the large virtual water availability, composing $70 \%$ of the planet, only a small percentage of $0.5 \%$ of fresh water is easily available in rivers, lakes and aquifers. However, the quality of these resources are being compromised as well - by irresponsible use of water resources and population growth, causing scarcity and, consequently, economic problem.

In this context, water springs are essential components for the maintenance of surface water resources. They are defined as the upwelling of groundwater that will give rise to a source of accumulated water, like lakes and ponds, or streams (rivulets, creeks and rivers). They have no well-defined place, and may be formed by an area, for example (CALHEIROS et al., 2009).

The Brazilian legislation through the "New Forest Code", Federal Law no 12,651, of May 25 ${ }^{\text {th }}, 2012$, in its Chapter II, Section I, article 4, section IV, considers as Permanent Preservation Area (PPA) "areas surrounding water springs and perennial waterholes, regardless of its topographical situation, in a radius of at least fifty (50) meters" (BRASIL, 2012). According to this definition, water springs and its surrounding vegetation are 
|Celso Henrique Leite Silva Junior | Denilson da Silva Bezerra | Vera Lúcia Araújo Bezerra|

| Gabrielle Vieira da Silva | Ana Talita Galvão Freire | Ana Emilia Figueiredo de Oliveira |

protected due to their fragility and utility, and can only be modified upon confirmed need for public utility. On consolidated rural areas, "it will be allowed the maintenance of agroforestry activities, ecotourism or rural tourism, being mandatory the recovery of at least fifteen (15) meters radius" (BRASIL, 2012).

Water springs environmental management is a technology based on hydrological behaviors of hydrographic basins, considering that such foundations vary in each ecosystem. Therefore, all parts of the hydrological cycle involved in the management of the springs occur in a surface area that meets the definition of hydrographic basin (VALENTE, 2009). Thus, it is possible to summarize that for the proper management of the water springs, it should be considered the relationships between the physical, biological and anthropic aspects in the context of the hydrographic basin. According to Rodrigues and Adami (2005), the context corresponds to a system that comprises a volume of materials, predominantly solid and liquid, near the earth's surface, internally and externally bounded by all processes that, from water availability by the atmosphere, interfere with the flow of matter and energy of a river or a network of river channels. Including therefore, all the spaces and circulation, storage, and exits of water and materials carried by the water that maintain relations with these channels.

In this context, the present study aims to propose a simplified methodology for quick environmental assessment of water springs to enable the monitoring and decisionmaking using the Fuzzy approach with the support of the Analytical Hierarchy Process AHP.

\section{STUDY AREA}

The island of Maranhão has an area of $1,453 \mathrm{~km}^{2}$ and is located between the geographic coordinates $02^{\circ} 23^{\prime} 00^{\prime \prime}, 02^{\circ} 47^{\prime} 00^{\prime \prime}$ south and $44^{\circ} 00^{\prime} 29^{\prime \prime}, 44^{\circ} 24^{\prime} 29^{\prime \prime}$ west, inserted in the Brazilian continental platform, in the middle of the Gulf of Maranhão and on the State's coast (RIOS, 2001). Its boundaries are: to the West, São Marcos Bay; to the North, the Atlantic Ocean; to the East, São José's Bay; and to the South, Estreito dos Mosquitos, at Arraial's Bay. The island is composed of four municipalities: São Luís, the State capital, São José de Ribamar, Paço do Lumiar and Raposa, counting 1,309,330 inhabitants in 2010 (IBGE, 2014).

The River Bacanga Hydrographic basin is located in the northwestern portion of the island of Maranhão, in the city of São Luís (MA), between the coordinates $2^{\circ} 32^{\prime} 26^{\prime \prime}$, 
|Celso Henrique Leite Silva Junior | Denilson da Silva Bezerra | Vera Lúcia Araújo Bezerra|

| Gabrielle Vieira da Silva | Ana Talita Galvão Freire | Ana Emilia Figueiredo de Oliveira |

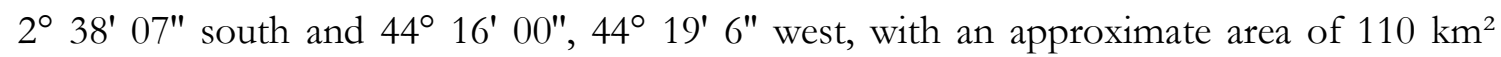
(equivalent to $12 \%$ of São Luís territory), with the main course extension of $22 \mathrm{~km}$, flowing into São Marcos’ Bay through a dam. Its limits are: to the North with São Marcos’ Bay and River Anil hydrographic basin; to the South, with Chapada do Tirirical; to the East, with Rivers Anil, Paciência and Cachorros Hydrographic Basins; and to the West, with River Itaqui Hydrographic Basin (MNT, 2007) (Figure 1).

Despite being the second most heavily urbanized basin in the city, it has an extensive vegetation coverage area forming two Conservation Units: Bacanga State Park where Batatã reservoir is located, responsible for $10 \%$ of the city of São Luís (MA) supply; and the Environmental Protection Area of Maracanã, which acts as a buffering zone between urban and industrial sprawl (NASCIMENTO, 2010).

The river springs mentioned by Vinhote (2008) were adopted for the environmental assessment: Spring 1, Spring 2, and Spring 3. Another eight springs, pointed out by residents of the basin area, were assessed, being named as follows: Spring 4, Spring 5, Spring 6, Spring 7, Spring 8, Spring 9, Spring 10, and Spring 11, totaling 11 springs for the assessment, according to Table 1 (Figure 1).

Table 1 - Springs identification: name, coordinates and altitude

\begin{tabular}{lll}
\hline Name & Coordinates (UTM) & Altitude \\
\hline Spring 1 & $579530 \mathrm{E} ;$ 9708547 S & $37 \mathrm{~m}$ \\
\hline Spring 2 & $578047 \mathrm{E} ; 9708542 \mathrm{~S}$ & $28 \mathrm{~m}$ \\
\hline Spring 3 & $576163 \mathrm{E} ; 9704600 \mathrm{~S}$ & $20 \mathrm{~m}$ \\
\hline Spring 4 & $580580 \mathrm{E} ;$ 9708404 S & $42 \mathrm{~m}$ \\
\hline Spring 5 & $580756 \mathrm{E} ; 9708163 \mathrm{~S}$ & $35 \mathrm{~m}$ \\
\hline Spring 6 & $579504 \mathrm{E} ; 9709514 \mathrm{~S}$ & $19 \mathrm{~m}$ \\
\hline Spring 7 & $580422 \mathrm{E} ; 9714694 \mathrm{~S}$ & $48 \mathrm{~m}$ \\
\hline Spring 8 & $580767 \mathrm{E} ; 9713533 \mathrm{~S}$ & $42 \mathrm{~m}$ \\
\hline Spring 9 & $583007 \mathrm{E} ; 9715988 \mathrm{~S}$ & $29 \mathrm{~m}$ \\
\hline Spring 10 & $580193 \mathrm{E} ; 9714657 \mathrm{~S}$ & $35 \mathrm{~m}$ \\
\hline Spring 11 & $582875 \mathrm{E} ; 9716212 \mathrm{~S}$ & $15 \mathrm{~m}$ \\
\hline Source: Prepared by the author. &
\end{tabular}


|Celso Henrique Leite Silva Junior | Denilson da Silva Bezerra | Vera Lúcia Araújo Bezerra | | Gabrielle Vieira da Silva | Ana Talita Galvão Freire | Ana Emilia Figueiredo de Oliveira |

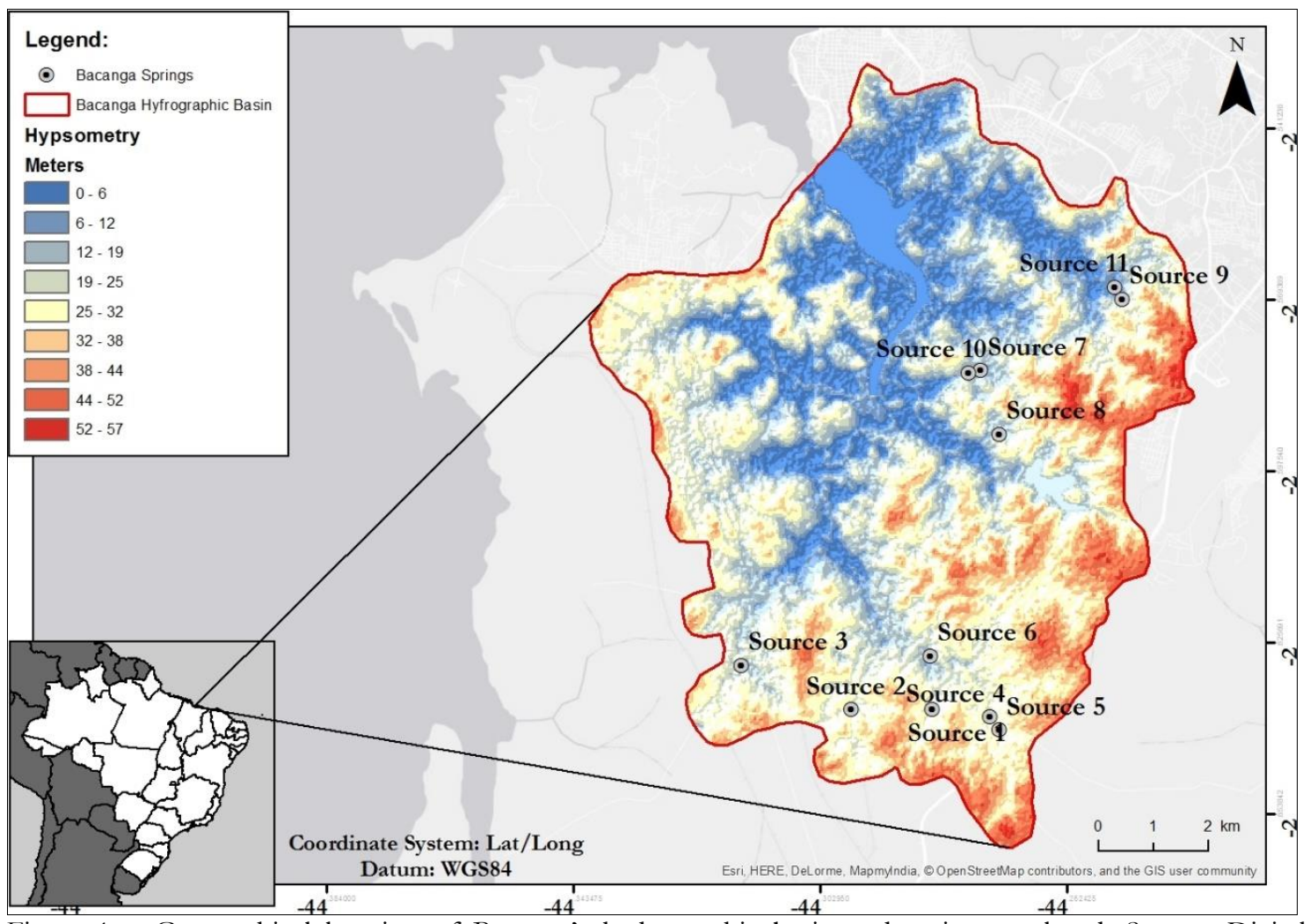

Figure 1 - Geographical location of Bacanga's hydrographic basin and springs analyzed. Source: Digital Terrain Model - DTM (Shuttle Radar Topography Mission - SRTM with 30 meters of spatial resolution).

\section{FUZZY LOGIC AND ANALYTIC HIERARCHICAL PROCESS - AHP}

The environmental analysis using Fuzzy Logic has shown efficiency in the treatment and synthesis of data compatible with reality. When combined with AHP (Analytic Hierarchy Process) technique, the uncertainties related to the analyzes are significantly reduced (PINESE JÚNIOR and RODRIGUES, 2012).

Zadeh (1965) developed the Theory of Fuzzy Sets (or diffuse sets). According to Aguado and Cantanhede (2010), the difference between Fuzzy logic and Boolean logic is the ability of the first to approach the real world where there are not only extreme responses, but also half terms. Fuzzy logic contains the possibility of measuring the degree of approximation of the exact solution and thus infer something that is necessary. Unlike Boolean logic, which only allows Boolean values - i.e., true or false (1 or 0) - Fuzzy logic deals with values ranging between 0 and 1 . A relevance of 0.5 can represent half true, then 0.9 and 0.1, represent almost true and almost false, respectively (RIGNEL et al., 2011).

Raffo (2012), points out that the Analytical Hierarchy Process is a mathematical methodology that has as its main purpose to quantitatively ponder variables by the interaction of the user with the mathematical model in a qualitative way. This method was developed by Saaty (1980). 
|Celso Henrique Leite Silva Junior | Denilson da Silva Bezerra | Vera Lúcia Araújo Bezerra|

| Gabrielle Vieira da Silva | Ana Talita Galvão Freire | Ana Emilia Figueiredo de Oliveira |

Pinese Júnior and Rodrigues (2012) add that the Analytic Hierarchy Process is the creation of a decision hierarchy, consisting in levels of importance that allow a global vision of the relationships inherent to the process. To establish the relative importance of each hierarchy factor, comparison matrices are elaborated for each level, where the results of the matrices are weighted against each other.

On the other hand, Silva and Nunes (2009) say that this process is based on pair comparison logic track (Pairwise Comparison) where different factors influencing in the decision-making are organized hierarchically and compared among themselves. A value of relative importance is assigned to the relationship between the factors, according to a predefined scale that expresses the intensity with which a factor predominates over another with regard to decision-making.

\section{METHODOLOGY}

This work was divided into four distinct stages, which consisted of: Bibliographic Survey, Field Data Collection, Data Processing and Tabulation, and Classification of the Springs, as shown in figure 2.

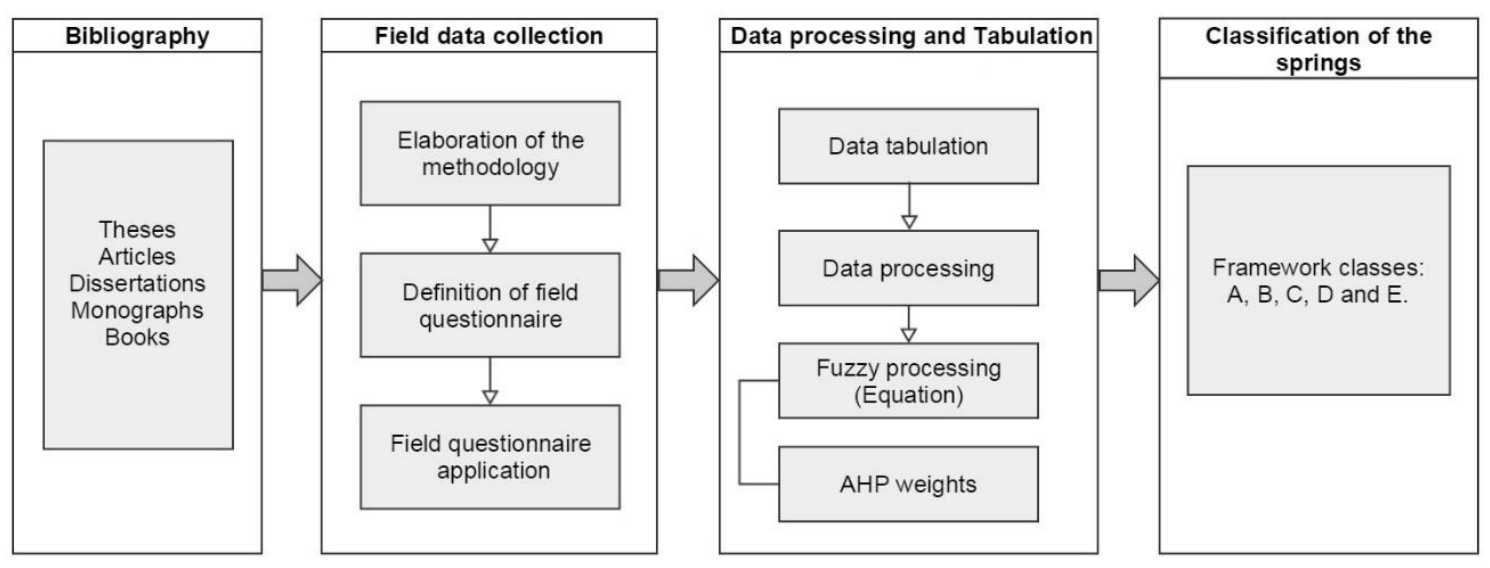

Figure 2 - Methodological research organization chart. Source: Prepared by the author.

First, a bibliographic survey related to the topics addressed in this paper was performed. Thesis, dissertations, laws, technical norms, and papers were used.

The field activities were performed from October $27^{\text {th }}, 2012$ to November $2^{\text {nd }}$, 2012. To collect data, we used a field questionnaire, with the help of the local community, to qualify the water springs through 11 parameters: water color, residues in the surroundings, oil, sewage, vegetation preservation, site protection, proximity to residences or establishments, insertion area type, odor and spumes and floating material. The 
|Celso Henrique Leite Silva Junior | Denilson da Silva Bezerra | Vera Lúcia Araújo Bezerra| | Gabrielle Vieira da Silva | Ana Talita Galvão Freire | Ana Emilia Figueiredo de Oliveira |

parameter water transparency was analyzed by visual inspection in a beaker, while the proximity to residences or establishments was measured by a measuring tape. The parameters and their qualifications are described in Table 2. A navigation GPS and a Photographic Camera were used to assist in the field activities.

In the laboratory, the AHP weights were calculated for each analyzed parameter and for the qualifications, through PriEsT 2.0 software (SIRAJ et al., 2013), where the value of RC: $0.0730(7.30 \%)$ was obtained. The AHP weights for each parameter are shown in "AHP Weights" column in Table 2 (BRASIL, 2012; GOMES et al., 2005; SILVA JUNIOR et al., 2013).

For the parameters qualifications (Qualifications Column), Fuzzy value of "0" for the column "Q1" was assigned where the qualifications were not available. In this case, in water springs that were dry; Fuzzy value of "0.334" for the qualifications of column "Q2"; Fuzzy value of "0.668" for the qualifications of column "Q3"; and finally, Fuzzy value of "1" for the qualifications of column"Q4". Values were assigned empirically based on already defined weights (GOMES et al., 2005).

Table 2 - Analyzed Parameters and their respective AHP weights and Qualifications (Fuzzy value).

\begin{tabular}{|c|c|c|c|c|c|}
\hline \multirow{2}{*}{$\begin{array}{c}\text { AHP } \\
\text { Weights }\end{array}$} & \multirow{2}{*}{ Parameters } & \multicolumn{4}{|c|}{ Qualification } \\
\hline & & Q1 & Q2 & Q3 & Q4 \\
\hline 0,182 & $\begin{array}{c}\text { Vegetation } \\
\text { preservation }\end{array}$ & Null & $\begin{array}{c}\text { High } \\
\text { degradation }\end{array}$ & $\begin{array}{c}\text { Low } \\
\text { degradation }\end{array}$ & Preserved \\
\hline 0,158 & Water color & Null & Dark & Clear & Transparent \\
\hline 0,139 & Sewage & Null & $\begin{array}{l}\text { Domestic } \\
\text { sewage }\end{array}$ & Surface flow & Without sewage \\
\hline 0,124 & Oils & Null & Very much & Little & Without oils \\
\hline 0,115 & $\begin{array}{l}\text { Residues in the } \\
\text { surroundings }\end{array}$ & Null & Very much & Little & No residue \\
\hline 0,069 & Site protection & Null & $\begin{array}{l}\text { Without } \\
\text { protection }\end{array}$ & $\begin{array}{c}\text { With } \\
\text { protection } \\
\text { and access } \\
\end{array}$ & $\begin{array}{l}\text { With protection } \\
\text { and no access }\end{array}$ \\
\hline 0,069 & $\begin{array}{l}\text { Proximity to } \\
\text { residences or } \\
\text { establishments }\end{array}$ & Null & $<50$ meters & $\begin{array}{c}\text { Between } 50 \\
\text { and } 100 \\
\text { meters }\end{array}$ & $>100$ meters \\
\hline 0,054 & $\begin{array}{c}\text { Insertion area } \\
\text { type }\end{array}$ & Null & Absent & $\begin{array}{c}\text { Private } \\
\text { property }\end{array}$ & Protected areas \\
\hline 0,034 & Floating material & Null & Very much & Little & Without floats \\
\hline 0,030 & Spume & Null & Very much & Little & No spume \\
\hline 0,026 & Odor & Null & Strong smell & Weak odor & No smell \\
\hline Q1: Fuzz & lue 0; Q2: Fuzz) & Value & 334; Q3: Fuzz & Value 0,$668 ;$ & 4: Fuzzy Value 1 \\
\hline
\end{tabular}


|Celso Henrique Leite Silva Junior | Denilson da Silva Bezerra | Vera Lúcia Araújo Bezerra |

| Gabrielle Vieira da Silva | Ana Talita Galvão Freire | Ana Emilia Figueiredo de Oliveira |

Data were tabulated and subsequently calculated using the operator Fuzzy AHP Weighted Mean equation, adapted from the weighted mean formula, in which the weighting was performed using AHP weights, Equation 1.

$$
I E Q_{W S}=\sum^{11} W P_{A H P} F P_{V}
$$

Where:

$I E Q_{W S}=$ Index of Environmental Quality of the Water Springs.

$W P_{A H P}=$ Weight of Parameter (AHP).

$F P_{V}=$ Fuzzy Parameter Value.

$11=$ Number of parameters.

To classify the springs, five environmental quality classes were used, each of them associated with an interval of a possible value of "IEQ" (Table 3).

Table 3 - Springs classification observed according to the value of "IEQs"

\begin{tabular}{ccc}
\hline Class & Environmental Quality & "IEQs" Value \\
\hline A & Very Good & $0,8-1$ \\
\hline B & Good & $0,6-0,8$ \\
\hline C & Reasonable & $0,4-0,6$ \\
\hline D & Bad & $0,2-0,4$ \\
\hline E & Very Bad & $0-0,2$ \\
\hline
\end{tabular}

Source: Prepared by the author.

\section{RESULTS}

Figure 3 shows the result of the photographic record of each spring. it is possible to see that Spring 1, Spring 4 and Spring 5 were dry at the time of assessment. 
|Celso Henrique Leite Silva Junior | Denilson da Silva Bezerra | Vera Lúcia Araújo Bezerra | | Gabrielle Vieira da Silva | Ana Talita Galvão Freire | Ana Emilia Figueiredo de Oliveira |

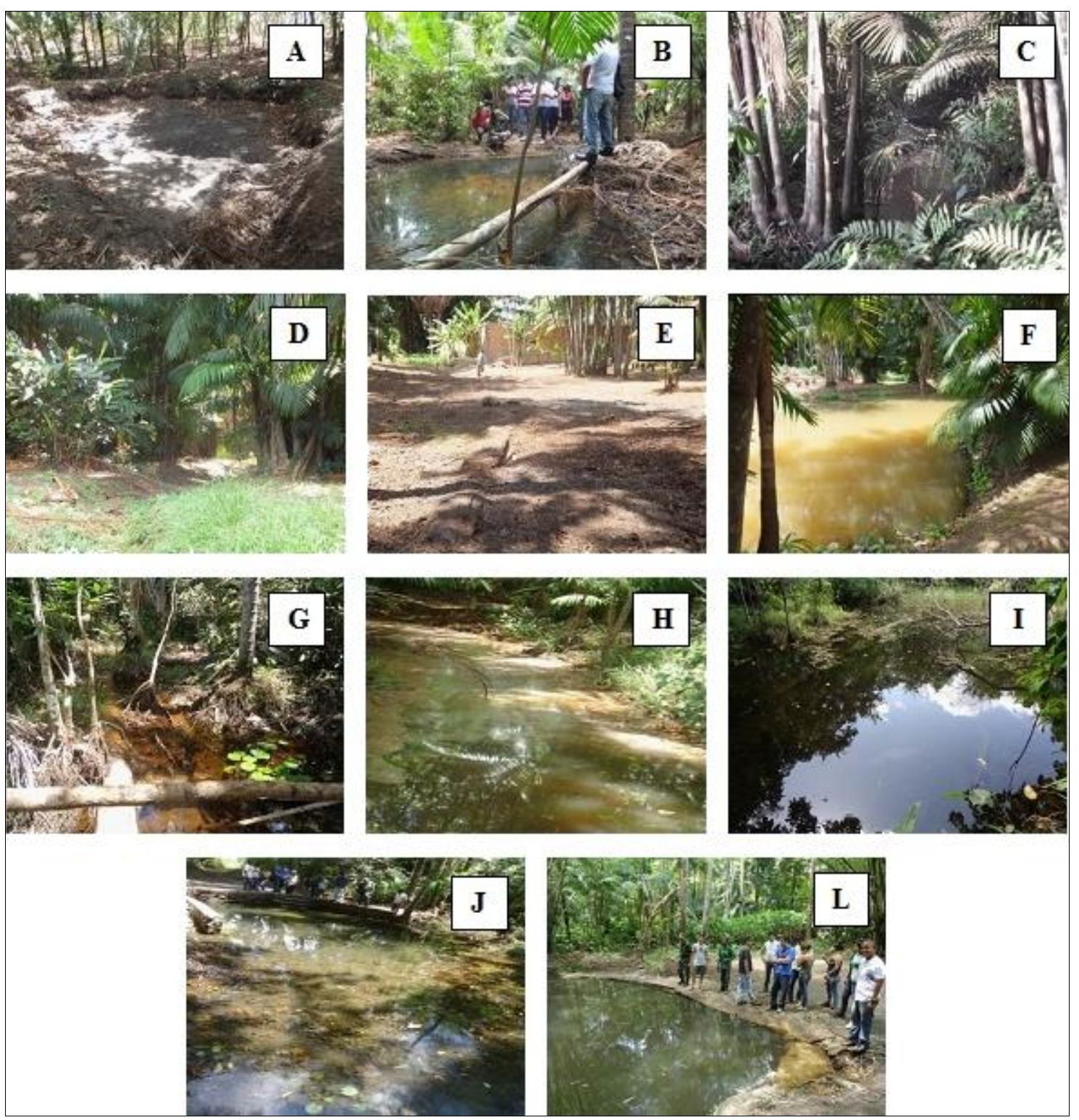

Figure 2 - Photographic record of analyzed springs. (A) Spring 1. (B) Spring 2. (C) Spring 3. (D) Spring 4. (E) Spring 5. (F) Spring 6. (G) Spring 7. (H) Spring 8. (I) Spring 9. (J) Spring 10. (L) Spring 11. Source: The authors.

The results of data collection related to Qualification values (Fuzzy values) and the Springs Environmental Quality Index (IEQ $)$ are presented in Table 4. On the same table, the column "Frequency (\%)" displays frequency of occurrence of ideal parameters qualification for each spring, being considered ideal those situations valued Q4. 
| Methodology for rapid assessment of environmental quality of water springs |

|Celso Henrique Leite Silva Junior | Denilson da Silva Bezerra | Vera Lúcia Araújo Bezerra | Gabrielle Vieira da Silva | Ana Talita Galvão Freire | |Ana Emilia Figueiredo de Oliveira |

Table 4 - Values and IEQ by parameter, and frequency of occurrence of spring's ideal qualifications

\begin{tabular}{|c|c|c|c|c|c|c|c|c|c|c|c|c|}
\hline \multirow{2}{*}{ Parameters } & \multicolumn{11}{|c|}{ Springs } & \multirow{2}{*}{$\begin{array}{c}\text { Frequency } \\
(\%)\end{array}$} \\
\hline & 1 & 2 & 3 & 4 & 5 & 6 & 7 & 8 & 9 & 10 & 11 & \\
\hline Water color & 0.000 & 0.668 & 0.334 & 0.000 & 0.000 & 0.668 & 1.000 & 0.668 & 1.000 & 1.000 & 0.668 & 27.27 \\
\hline $\begin{array}{l}\text { Residues in the } \\
\text { surroundings }\end{array}$ & 1.000 & 1.000 & 1.000 & 1.000 & 0.668 & 1.000 & 1.000 & 0.668 & 1.000 & 1.000 & 0.668 & 72.73 \\
\hline Oils & 0.000 & 1.000 & 1.000 & 0.000 & 0.000 & 1.000 & 1.000 & 1.000 & 1.000 & 1.000 & 1.000 & 72.73 \\
\hline Sewage & 1.000 & 1.000 & 1.000 & 0.334 & 0.334 & 1.000 & 1.000 & 1.000 & 1.000 & 1.000 & 1.000 & 81.82 \\
\hline Vegetation preservation & 1.000 & 1.000 & 1.000 & 0.668 & 0.668 & 1.000 & 1.000 & 0.668 & 1.000 & 1.000 & 1.000 & 72.73 \\
\hline Site protection & 1.000 & 0.668 & 1.000 & 1.000 & 0.668 & 1.000 & 0.668 & 0.668 & 0.668 & 0.668 & 0.668 & 36.36 \\
\hline $\begin{array}{l}\text { Proximity to residences } \\
\text { or establishments }\end{array}$ & 0.334 & 0.334 & 0.334 & 0.334 & 0.334 & 0.334 & 1.000 & 1.000 & 0.668 & 1.000 & 0.334 & 36.36 \\
\hline Insertion area type & 1.000 & 1.000 & 0.668 & 1.000 & 1.000 & 1.000 & 1.000 & 1.000 & 1.000 & 1.000 & 0.668 & 81.82 \\
\hline Odor & 0.000 & 1.000 & 0.668 & 0.000 & 0.000 & 1.000 & 1.000 & 1.000 & 1.000 & 1.000 & 1.000 & 63.64 \\
\hline Spume & 0.000 & 0.668 & 1.000 & 0.000 & 0.000 & 1.000 & 1.000 & 1.000 & 1.000 & 1.000 & 1.000 & 63.64 \\
\hline Floating material & 0.000 & 0.668 & 1.000 & 0.000 & 0.000 & 1.000 & 0.668 & 0.334 & 0.334 & 0.334 & 0.668 & 18.18 \\
\hline IEQS & 0.582 & 0.857 & 0.823 & 0.429 & 0.368 & 0.902 & 0.966 & 0.803 & 0.931 & 0.954 & 0.811 & \\
\hline Sources Class & $\mathrm{C}$ & $\mathrm{A}$ & $\mathrm{B}$ & $\mathrm{C}$ & $\mathrm{D}$ & $\mathrm{A}$ & $\mathrm{A}$ & $\mathrm{B}$ & $\mathrm{A}$ & $\mathrm{A}$ & $\mathrm{B}$ & \\
\hline
\end{tabular}

Source: Prepared by the author.

\begin{tabular}{|lllll|l}
\hline InterEspaço Grajaú/MA & v. 3, n. 8 & p. $07-26$ & jan./abr. 2017 & Página 17 \\
\hline
\end{tabular}


| Celso Henrique Leite Silva Junior | Denilson da Silva Bezerra | Vera Lúcia Araújo Bezerra | Gabrielle Vieira da Silva | Ana Talita Galvão Freire |

|Ana Emilia Figueiredo de Oliveira|

\section{DISCUSSION}

Regarding water color, only $27.27 \%$ (three water springs) showed transparent water color. Of the remaining eight water springs, three were dry (water spring 1, 4 and 5). Water color is an analytical parameter that indicates the presence of dissolved substances in the water, which results from the existence of substances in solution, that may be caused by elements such as iron or manganese, by the decomposition of organic material in the water (mainly plant matter), by algae or by the introduction of industrial and domestic sewage (SABESP, 2015; LQA, 2013). In regards to the three water springs that were dry, this phenomenon can be explained mainly because they did not present the minimum distance of $50 \mathrm{~m}$ established in the legislation, which may have affected the availability of water, allied to the fact that in the year 2012 rainfall was much lower than the average, due to the drought occurred in the Northeast region that year (LEIVAS et al., 2012; LEIVAS et al., 2014).

The performance and characteristics of the water springs are the results of the infiltration throughout the hydrographic basin and not only in the surrounding area of the spring. Consequently, the whole basin area deserves attention concerning preservation, which will determine the availability of water at the spring in quantity and stability over the year, including during the dry season (CALHEIROS et al., 2009). In general, in Maranhão, it is possible to observe that precipitation has decreased over the past years, which may cause future problems to these water springs (SILVA et al., 2014; 2016).

An important factor in the availability of water in these hydrological components is the need of underground water in the island of Maranhão. In this context, which includes wells with grant requests in the island, there was an increase in water use permit requests (2008 - 2012), that were generated by real estate, commercial and industrial growth. In the area, there are hundreds of wells in Bacanga basin which are drilled without permits for various purposes, thus, substantially affecting water availability of the water springs (FELIX et al., 2013).

Among the eleven springs, $72.73 \%$ did not present solid residues. Of the three that showed residues, two do not meet the minimum distance of 50 meters of residences and establishments, which facilitates the waste disposal. The imbalance of the fluvial system of River Bacanga's Hydrographic Basin is associated with many causes such as deforestation of its banks, dispersion of solid residues and biodiversity loss, thus compromising the 
|Celso Henrique Leite Silva Junior | Denilson da Silva Bezerra | Vera Lúcia Araújo Bezerra| | Gabrielle Vieira da Silva | Ana Talita Galvão Freire | Ana Emilia Figueiredo de Oliveira |

quality of life not only of the riverside communities, but of all adjacent area (SILVA et al., 2006).

About $72.73 \%$ of the water springs did not show oil in the water and $81.82 \%$ did not have sewage disposal. The two springs that had sewage disposal do not meet the minimum distance of 50 meters to residences and establishments. It was not possible to evaluate the remaining three water springs for the presence of oil, as they were dry and therefore they were assigned Fuzzy value null ("0"). The presence of oils is mainly linked to the disposal of domestic sewage in the water springs.

Regarding vegetation preservation, $72.73 \%$ of the springs presented existing and preserved vegetation, however, only 36.36\% (three water springs) were distanced more than 100 meters of residences and establishments, what is considered ideal. Only one water spring (water spring 9) is located at a minimum distance of 50 meters, attending the current federal legislation, and the other seven springs are located within less than 50 meters, in violation with the law.

It is observed that in local environmental legislation there are no restrictions and specific measures for water springs, only a general declaration that water bodies should be protected, more precisely, the vegetation cover that borders them. The Organic Law of the municipality of São Luís (SÃO LUÍS, 1990) as well as the Municipal Law Nº 3,253, of December $29^{\text {th }}, 1992$ (SÃO LUÍS, 1992), which regulates about zoning, parceling use and occupation of urban land and other measures, considers flora, or natural vegetation, located in waterholes and water springs as areas of relevant ecological interest (Art. 22, Art.181, \2, item II) and of Environmental Protection (Art.193, III), respectively. The Zoning Law (SÃO LUÍS, 1992) does not determine specific distance between water springs and construction projects, but it establishes a margin of 50 meters to water courses, upon approval of the competent authorities (Art.85). In relation to measures for conservation, according to the Environment Safety Code (State Law No. 5405 of August 04 ${ }^{\text {th }}$, 1992) (MARANHÃO, 1992), is state's responsibility to permanently preserve waterholes, springs, water sources and riparian vegetation (art.16, section XI), being considered of permanent preservation, areas and vegetation located in both springs of perennial nature and temporary ones, including waterholes (art. 54).

Only $36.36 \%$ of the springs are fenced. The other springs allow the entry of animals and people, which can compromise their structure. Regarding the insertion areas, about $81.82 \%$ of the springs are inserted in Conservation Units (CUs), this is due to Bacanga basin having in its area the Maracanã Environmental Protection Area and the State Park of 
|Celso Henrique Leite Silva Junior | Denilson da Silva Bezerra | Vera Lúcia Araújo Bezerra |

| Gabrielle Vieira da Silva | Ana Talita Galvão Freire | Ana Emilia Figueiredo de Oliveira |

Bacanga. In approximately $81.82 \%$ of the springs, the presence of sewage was not identified and $72.73 \%$ did not present residues in its surroundings.

Approximately $63.64 \%$ of the springs did not present odor. From the four remaining, three had dried up and one had odor due to sewage disposal on site. About $63.64 \%$ of the springs did not show spume in the water, whereas from the four remaining, three were found dry, and one, due to the presence of floating material (organic material) and its decomposition, presented spume in the water.

Only 18.18\% (two springs) did not show floating material. From the nine remaining, three springs were dried up and the other six had floating materials, mostly surrounding vegetation.

From the eleven springs analyzed, five were grouped in class A, with Excellent Environmental Quality; three were classified in class B, with Good Environmental Quality; two were framed in Class C, with Average Environmental Quality; and one fitted in class D, with Poor Environmental Quality, presenting a high degree of degradation, that is the adverse change of the environmental characteristics (BRASIL, 1981). There were no springs classified in class E, considered with Very Poor Environmental Quality.

In 2008, a study performed by Vinhote in the springs of Bacanga River located in Maracanã Environmental Protection Area - using his own methodology - found that only one of the eight identified and analyzed springs was found well preserved, since there were not many human occupations in the surroundings, nor areas of agriculture or open areas, and the vegetation was without significant changes. However, the other seven springs were found quite pressured by urban expansion, which is growing and expressive in the area of Maracanã (VINHOTE, 2008).

Great problems related to land use and occupation were identified not only in the immediate vicinity of the springs, but throughout the Bacanga Basin, where it can be observed the indiscriminate use and inappropriate soil management for agriculture and subsistence livestock. The disordered urban occupation, driven by population growth, is the degradation factor that stands out in Bacanga Basin and its springs. The establishment of industries in the area also has its share of contribution in the degradation of Bacanga's springs. Therefore, unplanned urbanization appears as the main factor of degradation of Bacanga's springs.

In terms of water resources, we observed researches that used the logical system in verifying the quality of waters (GARCIA et al., 2012; PEREIRA et al., 2012) and in characterizing the hydrographic basin (SILVA, 2005). Also, developed in São Luís, the 
|Celso Henrique Leite Silva Junior | Denilson da Silva Bezerra | Vera Lúcia Araújo Bezerra|

| Gabrielle Vieira da Silva | Ana Talita Galvão Freire | Ana Emilia Figueiredo de Oliveira |

work of Coelho (2008) sought to test the hypothesis of a cost-benefit relation between the existence of mangrove ecosystem and the loss of landscape in the urbanization process, where he designed a vulnerability index based on Fuzzy logic.

As a support method in environmental zoning, Fuzzy Logic is increasingly being used to support the analysis and criteria integration, a fact that gives advantages such as the reduction of possible errors, technique dissemination and improvement of its use (PAULA and SOUZA, 2007; OLIVEIRA et al., 2014). Nunes (2013) concluded in his work that the use of this tool produces indicators that may be used without restrictions, being an important and indispensable tool when working with data that have a high degree of uncertainty. Boclin and Mello (2006) and Liu et al. (2009) - who affirm that this method presents transparent results, easily understood by non-specialists and that contribute in decision making by assisting in forecasting future impacts - corroborate with this vision.

\section{FINAL REMARKS}

With the use of Fuzzy Logic integrated to AHP it was possible to treat problems related to the underestimation and overestimation of the environmental quality of the springs, since each parameter analyzed showed its respective weight value in the composition of the IEQ of each water spring.

It is recommended that for water springs classified on classes $C$ and $D$, mitigation measures for restoration and preservation should be taken, requiring first the isolation of the area in order to prevent the access of animals, people and vehicles. In addition, it is recommended the use of techniques that are already widespread in the scientific community, such as planting seedlings, nucleation, direct seeding, induction and/or conduction of natural regeneration for the recovery of the riparian vegetation, besides other procedures suggested by Calheiros et al. (2009) and actions established by CONAMA Resolution No. 429 of 2011 (BRASIL, 2011). It is also essential to this scenario, the fulfillment of what states art.190 of São Luís Organic Law (SÃO LUÍS, 1990), which provides for the signing of agreements with other municipalities of the island of Maranhão, to preserve its rivers and streams, promoting reforestation programs of the springs and banks of the water bodies.

Finally, we conclude that the methodology presented here is useful for a quick assessment with the purpose of preliminary decision-making, besides being useful for monitoring the springs. The methodology can also be applied and adapted to other regions. 
|Celso Henrique Leite Silva Junior | Denilson da Silva Bezerra | Vera Lúcia Araújo Bezerra| | Gabrielle Vieira da Silva | Ana Talita Galvão Freire | Ana Emilia Figueiredo de Oliveira |

\section{REFERENCES}

AguAdo, A. G.; CANTANHEDE, M. A. Lógica Fuzzy. 2010. Available at: < http://www.ft.unicamp.br/liag/wp/monografias/monografias/2010 IA FT UNICAM P logicaFuzzi.pdf $>$. Accessed on: 16 May. 2015, p. 12.

BARROS, F. G. N.; AMIN, M. M. Água: um bem econômico de valor para o Brasil e o mundo. Revista Brasileira de Gestão e Desenvolvimento Regional, Tabauté/SP, v. 4, n. $1, \quad$ p. 75-108, jan./abril. 2008. Available at: < http://www.rbgdr.net/012008/artigo4.pdf>. Accessed on: 16 May. 2015.

BOCLIN, A. S. C.; Mello, R. A decision support method for environmental impact assessment using a fuzzy logic approach. Ecological Economics, 2006, n. 58, p. $170-$ 181, 2005. Available at: $<$ http://faculty.mu.edu.sa/public/uploads/1338111017.4083EIA39.pdf >. Accessed on: 16 May. 2015.

BRASIL. Lei no 12.651, de 25 de Maio de 2012. Novo Código Florestal. Dispõe sobre a proteção da vegetação nativa. Brasília: Senado Federal, 2012. Available at: < http://www.planalto.gov.br/ccivil 03/ Ato2011-2014/2012/Lei/L12651.htm>.

Accessed on: 11 May. 2015.

BRASIL. Lei No 6.938, de 31 de Agosto de 1981. Dispõe sobre a Política Nacional do Meio Ambiente, seus fins e mecanismos de formulação e aplicação, e dá outras providências. Available at: <http://www.planalto.gov.br/ccivil 03/leis/L6938.htm>. Accessed on: 11 May. 2015.

BRASIL. Resolução Conama no 429, de 28 de Fevereiro de 2011. Dispõe sobre a metodologia de recuperação das Áreas de Preservação Permanente - APPs. Available at: $<$ http://www.mma.gov.br/port/conama/legiabre.cfm?codlegi=644> $>$. Accessed on: 25 May. 2015.

CALHEIROS, R. O.; TABAI, F. C. V.; BOSUILIA, S. V.; CALAMARI, M. Preservação e recuperação das nascentes de água e vida. In: Cadernos da Mata Ciliar, SIGAM, São Paulo, n. 1, 36p. 2009. Available at: < http://www.sigam.ambiente.sp.gov.br/sigam2/Repositorio/222/Documentos/Cadernos Mata Ciliar 1 Preservacao Nascentes.pdf>. Accessed on: 18 May. 2015.

COELHO, C. J. C. Lógica Fuzzy e o Geoprocessamento na determinação da vulnerabilidade à ocupação direta dos mangues na Bacia Hidrográfica do Anil na Ilha de São Luís-MA. 2008. Dissertação (Mestrado em Sustentabilidade de Ecossistemas) - Universidade Federal do Maranhão, São Luís/MA, 2008.

FELIX, A. S.; NASCIMENTO, S. F.; SILVA JUNIOR, C. H. L.; BEZERRA, V. L. A. R. O uso da água outorgada na Ilha de São Luís no período de 2008 a 2012. In: SIMPÓSIO BRASILEIRO DE RECURSOS HÍDRICOS, 20., Bento Gonçalves/RS, 2013. Anais eletrônicos... Bento Gonçalves/RS: ABRH, 2013. p. 1-8.

GARCIA, H. L.; SILVA, V. L.; MARQUES, L. P.; GARCIA, C. A. B.; CARVALHO, F. O. Avaliação da qualidade da água utilizando a teoria Fuzzy. Scientia Plena, n. 8, p. 1-10, 2012. 
|Celso Henrique Leite Silva Junior | Denilson da Silva Bezerra | Vera Lúcia Araújo Bezerra| | Gabrielle Vieira da Silva | Ana Talita Galvão Freire | Ana Emilia Figueiredo de Oliveira |

GOMES, P. M.; MELO, C.; VALE, V.S. Avaliação dos impactos ambientais em nascentes na cidade de Uberlândia/MG: análise macroscópica. Sociedade e Natureza, v. 17, n. 32, p. 103-120, 2005.

IBGE - Instituto Brasileiro de Geografia e Estatística. Censo Demográfico. 2014. Available at: < http://www.sidra.ibge.gov.br> $>$. Accessed on: 20 May. 2015.

LEIVAS, J.; ANDRADE, R. G.; VICTORIA, D. de C.; TORRESAN, F. E.; BOLFE, E. L.; Barros, T. Monitoramento da seca ocorrida em 2012 no Nordeste brasileiro a partir dos dados do Spot-Vegetation e TRMM. In: SIMPÓSIO REGIONAL DE GEOPROCESSAMENTO E SENSORIAMENTO REMOTO ANAIS, 6., Aracaju/SE, 2012. Anais eletrônicos... Aracaju/SE: RESGEO, 2012.

LEIVAS, J.; ANDRADE, R. G.; VICTORIA, D. de C.; TORRESAN, F. E.; BOLFE, E. L. Monitoramento da seca 2011/2012 no Nordeste brasileiro a partir do satélite SpotVegetation e TRMM. Engenharia na Agricultura, Brasília/DF, v. 22, n. 3, p. 211-221. 2014. Disponível em: < https://goo.gl/H0F6GO>. Acesso em: 29 mar. 2017.

LINHARES, C. G.; GUSSEN, C. T. G.; RIBAS, J. R. O método fuzzy ahp aplicado à análise de riscos de usinas hidrelétricas em fase de construção. In: CONGRESSO LATINO-IBEROAMERICANO DE INVESTIGAÇÃO OPERACIONAL, Rio de Janeiro/RJ, 2012. Anais eletrônicos... Rio de janeiro/RJ: SOBRAPO, 2012.

LIU, K. F. R.; LIANG, H. H.; YEH, K.; CHEN, C. W. A qualitative decision support for environmental impact assessment using Fuzzy logic. Journal of Environmental Informatics, 2009, n. 13(2), p. 93-103.

LQA - Laboratório de Qualidade de Água do Departamento de Engenharia Agrícola e Ambiental. Qualidade da Água. Viçosa: Universidade Federal de Viçosa, 2013. Available at: <http://www.ufv.br/dea/lqa/qualidade.htm>. Accessed on: 11 may. 2015.

MARANHÃO. Lei no 5.405, de 08 de Abril de 1992. Código de proteção de meio ambiente do Estado do Maranhão. Available at: < http://saoluis.ma.gov.br/custom files/File/LEI5405.pdf > . Accessed on: 25 may. 2015.

MMT - MMT Planejamento e Consultoria. Programa de recuperação e melhoria da qualidade de vida do Bacanga. São Luís/MA: MMT, 2007.

NASCIMENTO, J. D. Índice de sustentabilidade ambiental do uso da água (ISA) como ferramenta de contribuição às Políticas Públicas de desenvolvimento $\mathrm{e}$ conservação na Bacia do Rio Bacanga, São Luís/MA. 2010. Dissertação (Mestrado em Sustentabilidade de Ecossistemas) - Universidade Federal do Maranhão, São Luís/MA, 2010.

NUNES, M. M. P. A. Métodos para Avaliação de Impactos Ambientais: A Lógica Fuzzy como Ferramenta de Tomada de Decisões. 2013. Trabalho de Conclusão de Curso (Curso Superior de Engenharia Ambiental) - Universidade Tecnológica Federal do Paraná, Londrina/PR, 2013. 
|Celso Henrique Leite Silva Junior | Denilson da Silva Bezerra | Vera Lúcia Araújo Bezerra| | Gabrielle Vieira da Silva | Ana Talita Galvão Freire | Ana Emilia Figueiredo de Oliveira |

OLIVEIRA, F. B.; OLIVEIRA, C. H. R.; LIMA, J. S. S.; RIBEIRO FILHO, R. B.; MIRANDA, M. R.; NEVES, L. Z.; FERRAZ, F. Aplicação de geoprocessamento e lógica Fuzzy para criação de zoneamento no Parque Estadual da Cachoeira da Fumaça/ES para fins de conservação. Revista Brasileira de Cartografia, Rio de Janeiro, 2014, n. 66/3, p. 545-554, may./jun. $2014 . \quad$ Available at: $<$ www.lsie.unb.br/rbc/index.php/rbc/article/download/646/699>. Accessed on: 16 may. 2015.

PAULA, E. M. S.; SOUZA, M. J. N. Lógica Fuzzy como técnica de apoio ao Zoneamento Ambiental. In: SIMPÓSIO BRASILEIRO DE SENSORIAMENTO REMOTO, 13., 2017, Florianópolis/SC. Anais eletrônicos... Florianópolis/SC: INPE, 2007.

PEREIRA, A. A.; OCAZIONEZ, S. A. C.; Tomaz, C. Avaliação da qualidade da água: proposta de novo índice alicerçado na lógica Fuzzy. Bioscience Journal, Uberlandia/MG, v. 28, n. 4, p. 667-677, july/aug. 2012. Available at: $<\underline{\text { http://www.seer.ufu.br/index.php/biosciencejournal/article/view/12577>. Accessed }}$ on: 16 may. 2015.

PINESE JÚNIOR, J. F.; RODRIGUES, S. C. O método de análise hierárquica - AHP como auxílio na determinação da vulnerabilidade ambiental da bacia hidrográfica do Rio Piedade (MG). Revista do Departamento de Geografia - USP, São Paulo, 2012, v. 23, p. 4-26, 2012. Available at: <http://www.revistas.usp.br/rdg/article/view/47203/50939>. Accessed on: 16 may. 2015.

PUP - Planet Under Pressure. Recomendações para a RIO+20. Segurança hídrica para um planeta sob pressão - Transição para a sustentabilidade: desafios interligados e soluções. Conferência Internacional Planet under Pressure: New Knowledge Towards Solutions. The International Project Office of the Global Water System Project. Available at: < http://www.planetunderpressure2012.net >. Accessed on: 20 may. 2015.

RAFFO, J. G. de G. O processo analítico e seu uso na modelagem do espaço geográfico. Revista do Departamento de Geografia - USP, São Paulo, 2012, v. 23, p. 26-37, 2012. Available at: $<$ http://www.revistas.usp.br/rdg/article/view/53840/57803 $>$. Accessed on: 20 may. 2015.

RIGNEL, D. G.; CHENCI, G. P.; LUCAS, C. Uma introdução a Lógica Fuzzy. Revista Eletrônica de Sistemas de Informação e Gestão Tecnológica, 2011, v. 1, n. 1, p. 17-28. $2011 . \quad$ Available at: $<$ http://periodicos.unifacef.com.br/index.php/resiget/article/view/153/10>. Accessed on: 20 may. 2015.

RIOS, L. Estudos de Geografia do Maranhão. 3. ed. São Luís/MA: Gráphis, 2001.

RODRIGUES, C.; ADAMI, S. Técnicas fundamentais para o estudo de bacias hidrográficas. Praticando geografia: técnicas de campo e laboratório em geografia e análise ambiental. São Paulo: Oficina de Textos, 2005.

SAATY, T. L. The Analytic Hierarchy Process: planning, priority setting, resource allocation. New York/USA: Mcgraw-hill, 1980. 
|Celso Henrique Leite Silva Junior | Denilson da Silva Bezerra | Vera Lúcia Araújo Bezerra| | Gabrielle Vieira da Silva | Ana Talita Galvão Freire | Ana Emilia Figueiredo de Oliveira |

SABESP - Companhia de Saneamento Básico do Estado de São Paulo. Qualidade da Água. Available at: < http://site.sabesp.com.br/site/interna/Default.aspx?secaoId $=40>$. Accessed on: 20 may. 2015.

SÃO LUÍS. Lei no 3.253, de 29 de Dezembro de 1992. Código de Posturas do município de São Luís. Available at: <http://www2.saoluis.ma.gov.br/POLITICAURBANA/download/leis/vigente/LEI ZO NEAMENTO VIGENTE.pdf>. Accessed on: 25 may. 2015.

SÃO LUÍS. Lei Orgânica do Município de São Luís, de 05 de Abril de 1990. Available at: $<$ http://www2.saoluis.ma.gov.br/custom files/File/LEI\%20ORGANICA\%20complet a.pdf $>$. Accessed on: 25 may. 2015.

SILVA JUNIOR, C. H. L.; FELIX, A. S.; NASCIMENTO, S. F.; BEZERRA, V. L. A. R. Avaliação ambiental preliminar das nascentes do rio Bacanga, São Luís/MA. In: SIMPÓSIO BRASILEIRO DE RECURSOS HÍDRICOS, 20., Bento Gonçalve/RS, 2013. Anais eletrônicos... Bento Gonçalves/RS: ABRH, 2013.

SILVA, C. A. de; NUNES, F. P. Mapeamento de vulnerabilidade ambiental utilizando o método AHP: uma análise integrada para suporte à decisão no município de Pacoti/CE. In: SIMPÓSIO BRASILEIRO DE SENSORIAMENTO REMOTO, 14., Natal/RN, 2009. Anais eletrônicos... Natal/RN: INPE, 2009.

SILVA, F. B. et al. Evidências de Mudanças Climáticas na Região de Transição Amazônia Cerrado no Estado do Maranhão. Revista Brasileira de Meteorologia, v. 31, n. 3, p. 330 $-336,2016$.

SILVA, F. B.; SANTOS, J. R. N.; ARAUJO, M. L. S.; SILVA JUNIOR, C. H. L. Análise espaço-temporal da precipitação no estado do Maranhão no período de 2003 a 2012. In: PROCEEDINGS OF SAFETY, HEALTH AND ENVIRONMENT WORLD CONGRESS, 14., Cubatão/SP, 2014. Anais eletrônicos... Cubatão/SP: COPEC, 2014.

SILVA, G. da S; FERREIRA, F. G. de S.; FERREIRA, L. C.; BATALHA, M. A. de J.; DIAS, L. J. da S. Análise geomorfológica do sistema de drenagem do baixo rio Bacanga: São Luís/MA. In VI SIMPÓSIO NACIONAL DE GEOMORFOLOGIA, 6., Goiânia/GO, 2006. Anais eletrônicos... Goiânia/GO: IAG, 2006.

SILVA, S. F. Zoneamento geoambiental com auxílio de lógica Fuzzy e proposta de um geoindicador para caracterização do meio físico para da Bacia do Rio Peixe. 2005. Tese (Doutorado em Geotecnia) - Escola de Engenharia de São Carlos, Universidade de São Paulo, São Carlos/SP, 2005.

SIRAJ, S.; MIKHAILOV, L.; KEANE, J. A. PriEsT: an interactive decision support tool to estimate priorities from pairwise comparison judgments. International Transactions in Operational Research, n. 2013, p. 1-19, 2013.

UN - United Nations. Relatório Mundial das Nações Unidas sobre o Desenvolvimento dos Recursos Hídricos. O manejo dos recursos hídricos em condições de incerteza e risco - Fatos e Dados (WWDR4 - World Water Development Report 4). 4. ed. Publicado pela Organização das Nações Unidas para a Educação, a 
|Celso Henrique Leite Silva Junior | Denilson da Silva Bezerra | Vera Lúcia Araújo Bezerra|

| Gabrielle Vieira da Silva | Ana Talita Galvão Freire | Ana Emilia Figueiredo de Oliveira |

Ciência e a Cultura (UNESCO), 2012. Available at: <http://www.planetunderpressure2012.net>. Accessed on: 20 may. 2015.

VALENTE, O. F. Hidrologia e manejo de pequenas bacias hidrográficas: conservação de nascentes. 2009. Available at: $<$ http://shar.es/G7LnE $>$. Accessed on: 16 may. 2015

VINHOTE, E. C. A. Sustentabilidade das formas de ocupação, uso e conservação das matas ciliares nas nascentes do rio Bacanga de São Luís - MA. 2008. Dissertação (Mestrado em Sustentabilidade de Ecossistemas) - Universidade Federal do Maranhão, São Luís/MA, 2008.

ZADEH, L. A. Fuzzy sets and systems. In: FOX, J. (Ed.). Systems theory. New York/USA: Polytechnic Press, 1965. 